\title{
A scientific note on the arrival of the dwarf honeybee, Apis florea (Hymenoptera: Apidae), in Djibouti
}

\author{
Warren E. STEINER Jr \\ Department of Entomology, NHB-187, Smithsonian Institution, Washington, DC 20560, USA
}

Received 14 December 2016 - Revised 28 March 2017 - Accepted 13 April 2017

Apis florea / Djibouti / new country record / pollination / invasive species

Among the many Hymenoptera and other insects collected on two biological diversity survey expeditions conducted by the Smithsonian Institution at Camp Lemonnier, Djibouti, Horn of Africa, in May 2014 and February 2016, were specimens of the dwarf honeybee, Apis florea F. (Figure 1). This bee is recognized as invasive (Bezabih et al. 2014; Moritz et al. 2010) and spreading from its native Asian range through the Middle East and southward into north eastern Africa, and recently reported in northern Ethiopia (Pauly and Hora 2013). The discovery of the first African introduction near Khartoum, Sudan, in 1985 was presumed to have originated from Pakistan by air cargo (Lord and Nagi 1987; Mogga and Ruttner 1988). This is the first report of the species occurring in Djibouti.

Moritz et al. (2010) discussed the uncertain impacts of the arrival of $A$. florea to agriculture, apiculture, and biodiversity conservation. On the military base of Camp Lemonnier, it was found to be more of a nuisance pest, attracted to liquids and run-off from air conditioning units; a nest colony was removed from a building site on the base, and a second active nest was observed on a stack of stored lumber. While not a very aggressive bee (Moritz et al. 2010), it is apparently becoming synanthropic and accidental stings could be a potential human health problem. Studies have shown (El Shafie et al. 2002) that $A$. florea is not very competitive with Apis mellifera $\mathrm{L}$. and its subspecies, the most commercially valuable honey bees, and that its pollination services could outweigh any negative impacts. However, native bees are probably already providing these ser-

Corresponding author: W. Steiner, steinerw@si.edu Manuscript editor: Stan Schneider vices to the local flora and crops, and their populations would certainly be impacted by arrival of an exotic species. Nine species of solitary bees, so far unidentified, were found among the collected samples with $A$. florea. More sampling at different times of the year would likely detect a richer bee fauna. The vegetation on and around the base is however dominated by the non-native Prosopis glandulosa Torr. (Fabaceae) which, while considered a valuable "honey plant," has probably impacted the native biota in unknown ways.

Specimens are deposited in the United States National Museum of Natural History, Smithsonian Institution, Washington, DC, USA. Specimen label data below are quoted verbatim, with commas inserted for clarity; breaks between labels are separated by a forward slash. The numbers of specimens bearing the same data follow in parentheses.

Specimens examined.--"DJIBOUTI: Djb. Region; Camp Lemonnier, base sport field, $5 \mathrm{~km} \mathrm{~S}$ Djibouti, $11^{\circ}$ $32^{\prime} 33^{\prime \prime} \mathrm{N}, 43^{\circ} 08^{\prime} 14.7^{\prime \prime} \mathrm{E}, 5 \mathrm{~m}$; 2 May 2014/on ground under lights after dark, open dry soil; Colls. W. E. Steiner, et al." (1); "DJIBOUTI: Djb. Region; Camp Lemonnier, central base, $\mathrm{m} ; 5 \mathrm{~km} \mathrm{~S}$ Djibouti, $11^{\circ} 32^{\prime}$ $34^{\prime \prime} \mathrm{N}, 43^{\circ} 08^{\prime} 57^{\prime \prime} \mathrm{E}$, nest taken 2 May 2014, W. E. Steiner, et al." (62); same data except specimens in genomics biorepository, numbers "AA8I-O50" and "AA8I-O51" (2); "DJIBOUTI: Djb. Region; Camp Lemonnier, Ditch, $5 \mathrm{~km}$ SSE Djibouti, $11^{\circ} 32^{\prime} 27^{\prime \prime} \mathrm{N}$, $43^{\circ} 10^{\prime} 12^{\prime \prime}$ E, 2 m; 13 Feb. 2016, Sweep net; C. Johnson" (1); "DJIBOUTI: Djb. Region; Camp Lemonnier, E. end of base at ditches, $5 \mathrm{~km}$ SSE Djibouti, $11^{\circ} 32^{\prime} 27.6^{\prime \prime} \mathrm{N}, 43^{\circ} 10^{\prime} 15^{\prime \prime}$ E, 2 m; 3-6 May 2014/yellow bowl traps, open Prosopis and Acacia scrub near freshwater ditches on dry sandy soil; W. E. Steiner, et al." (8); "DJIBOUTI: Djb. Region; Camp Lemonnier, eastern end of base, $5 \mathrm{~km} \mathrm{SSE} \mathrm{Djibouti,} 11^{\circ}$ 


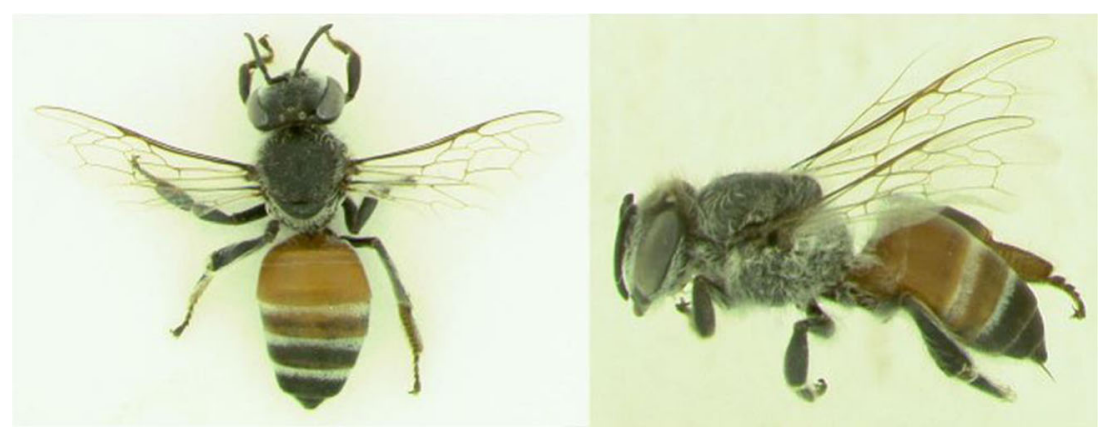

Figure 1. Specimens of Apis florea collected on Camp Lemonnier, Djibouti. Length $8 \mathrm{~mm}$.

$32^{\prime} 29^{\prime \prime}$ N, 43 10' 07" E, 2 m; 3-6 May 2014/yellow bowl trap on open powdery soil near small ditch; W. E. Steiner, et al." (14); "DJIBOUTI: Djb. Region; 5 km SSE Djibouti, Gulf of Aden coast east of Camp

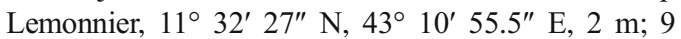
May 2014/at black light among shrubs, small dune near beach; W. E. Steiner, et al." (1).

The first record of $A$. florea from northern Ethiopia (Pauly and Hora 2013) was a single specimen collected in 2011, and figured in that paper along with subsequently discovered nests and habitat images. These records and those reported by Bezabih et al. (2014) were at higher elevations in agricultural and forested areas, very different from the low coastal sites at Camp Lemonnier. Bezabih et al. (2014) wrote that "it can also be expected to expand into the lowlands of Eritrea." The Djibouti records indicate that it probably has spread throughout Eritrea and probably now occurs in Somalia; the spread throughout most of Africa is likely (Dietemann et al. 2009; Bezabih et al. 2014) and finding $A$. florea in the low desert habitats and human-disturbed parts of Djibouti, with average high temperatures of $29-41^{\circ} \mathrm{C}$, supports this prediction. An eventual cosmopolitan distribution seems probable. Prevention of transport of colonies by ship or air cargo should be a priority.

Of the ten species of bees detected in the insect survey on and near Camp Lemmonier, A. florea was the most common species observed; it was seen visiting flowers of Acacia spp. (Fabaceae) and Heliotropium pallens Delile (Boraginaceae). It is not considered to be a commercially valuable honey producer like the larger A. mellifera. Beekeeping is apparently not done on Camp Lemonnier and the surrounding scrub habitats that could provide nest sites for wild $A$. mellifera are few. No A. mellifera were collected or seen during the surveys; A . mellifera jemenitica Ruttner has been reported (Pauly and Hora 2013) from Obock, northern Djibouti.

\section{ACKNOWLEDGEMENTS}

The project was funded by the US Navy (Natural Resources Program) and the Smithsonian Institution's Global Genome Initiative. Permits and logistical advice were provided by Houssein Rirache Robleh, Environmental Management Department, Ministry of Environment, Djibouti. Many members of the field teams and others (Ishman Bucul, Carla Dove, Steve Gotte, Jeremy Jacobs, Connie Johnson, Matt Klope, Calvin Lotiaco, Suzy Peurach, Lisa Rowe, Rusty Russell, Jacob Saucier, Reggie Spence, Kirk Stevens, Jim Whatton) provided help in many ways with entomological work. A review and comments on an early draft by Dr. Robin F. A. Moritz, Institut für Biologie, MartinLuther-Universität Halle-Wittenberg, and reviews by two anonymous specialists, greatly improved this note.

Une note scientifique sur l'arrivée de l'abeille naine, Apis florea (Hymenoptera: Apidae), à Djibouti

Eine wissenschaftliche Notiz zum Nachweis der Zwerghonigbiene Apis florea (Hymenoptera: Apidae) in Dschibuti

\section{REFERENCES}

Bezabih G., Adgaba N., Hepburn H.R., Pirk C.W.W. (2014) The territorial invasion of Apis florea in Africa. Afr. Entomol. 22(4), 888-890

Dietemann V., Pirk C.W.W., Crewe R. (2009) Is there a need for conservation of honeybees in Africa? Apidologie 40, 285-295

El Shafie H.A.F., Mogga J.B.B., Basedow T. (2002) Studies on the possible competition for pollen between the honey bee, Apis 
mellifera sudanensis, and the imported dwarf honey bee Apis florea (Hym., Apidae) in North-Khartoum (Sudan). J. Appl. Entomol. 126, 557-562

Lord W.G., Nagi S.K. (1987) Apis florea discovered in Africa. Bee World 68, 39-40

Mogga G.B., Ruttner F. (1988) Apis florea in Africa: source of the founder population. Bee World 69, 100-103
Moritz R.F.A., Haddad N., Bataieneh A., Shalmon B., Hefetz A. Israel Nature \& Parks Authority (2010) Invasion of the dwarf honeybee Apis florea into the near East. Biol. Invasions 12, 1093-1099

Pauly A., Hora Z.A. (2013) Apini and Meliponini from Ethiopia (Hymenoptera: Apoidea: Apidae: Apinae), Belg. J. Entomol. $16,1-35$ 